\title{
Prognostic impact of peritumoral lymphocyte infiltration in soft tissue sarcomas
}

\author{
Sveinung W Sorbye ${ }^{1,2^{*}}$, Thomas K Kilvaer ${ }^{2}$, Andrej Valkov ${ }^{1,2}$, Tom Donnem, ${ }^{3,4}$ Eivind Smeland ${ }^{5}$, Khalid Al-Shibli, ${ }^{2,5}$,
} Roy M Bremnes ${ }^{3,4}$ and Lill-Tove Busund ${ }^{1,2}$

\begin{abstract}
Background: The purpose of this study was to clarify the prognostic significance of peritumoral lymphocyte infiltration in the capsule of soft tissue sarcomas (STS). Multiple observations in preclinical and clinical studies have shown that the immune system has a role in controlling tumor growth and progression. Prognostic markers in potentially curable STS should guide therapy after surgical resection. The immune status at the time of resection may be important, but the prognostic significance of peritumoral lymphocytes is unknown.
\end{abstract}

Methods: Tissue microarrays from 80 patients with STS were constructed from duplicate cores of tissue from the tumor and the peritumoral capsule. Immunohistochemistry was used to evaluate the CD3+, CD4+, CD8+ and CD20 + lymphocytes in the tumor and the peritumoral capsule.

Results: In univariate analyses, increasing numbers of CD20+ $(P=0.032)$ peritumoral lymphocytes were associated with a reduced disease free survival (DSS). In multivariate analyses, a high number of CD20+ peritumoral lymphocytes $(P=0.030)$ in the capsule was an independent negative prognostic factor for DSS. There were no such associations of lymphocyte infiltration in the tumor.

Conclusions: A high density of CD20+ peritumoral lymphocytes is an independent negative prognostic indicator for patients with STS. Further research is needed to determine whether CD20 cells in the peritumoral capsule of STS may promote tumor invasion in the surrounding tissue and increase the metastatic potential.

\section{Background}

Soft tissue sarcomas (STS) are relatively rare heterogeneous malignancies of mesenchymal origin with a high mortality rate. They comprise less than $1 \%$ of adult malignancies [1]. Approximately 50\% of STS patients will succumb to their disease because of metastasis or local relapse [2]. There are several prognostic factors that determine tumour progression and, ultimately, a patients' fate. These include tumour grade, size, location, depth, histological entity, positive resection margins, and presence of local recurrence [3-9].

There are three groups of tumor infiltrating lymphocytes: (a) lymphocytes within cancer cell nests (intratumoral lymphocytes); (b) lymphocytes in the central cancer stroma (stromal lymphocytes), and; (c) lymphocytes present along the invasive margins (peritumoral

\footnotetext{
* Correspondence: sveinung.sorbye@unn.no

'Dept of Clinical Pathology, University Hospital of North Norway, 9038

Tromso, Norway Full list of author information is available at the end of the article
}

lymphocytes) [10]. Soft tissue sarcomas are by definition stromal tumores. But from a biological point of view any tissue must have both parenchyma and supporting stroma. For STS it can be both internal tissue and surrounding tissue.

In a previous paper we reported the prognostic significance of lymphocyte infiltration in tumors [11]. The purpose of this study was to clarify the prognostic significance of lymphocyte infiltration in the peritumoral capsule of STS patients. This was achieved by analyzing the expression of $\mathrm{CD} 3+, \mathrm{CD} 4+, \mathrm{CD} 8+$ and $\mathrm{CD} 20+$ lymphocytes in the peritumoral capsule from 80 patients with non-gastrointestinal stromal tumors (non-GIST) STS, in relation to other clinico-pathological variables.

Stromal cells include (myo)fibroblasts, vascular cells, infiltrating leukocytes and specialized mesenchymal support cells unique to each organ microenvironment. Multiple observations in preclinical and clinical studies support a role for the immune system in controlling
C Biomed Central 
tumor growth and progression. However, the effects of the immune system may be contradictory because activation of the adaptive immune system may suppress malignant cells, whereas activation of various types of innate immune cells may promote tumor growth [12]. The adaptive immunity is brought about by antigen-specific $\mathrm{T}$ and B-lymphocytes; tumor growth is inhibited through direct killing by cytotoxic T-lymphocytes, as well as a combination of cytokine-mediated and antibody-mediated tumor cell lysis [12].

CD3 is a part of the T cell receptor (TCR) complex on mature $\mathrm{T}$ lymphocytes. The two major $\mathrm{T}$ lymphocyte subsets are (1) T helper cells (Th, CD4+) and (2) cytotoxic $\mathrm{T}$ cells (CTL, CD8+). CD4 is a glycoprotein expressed on the surface of $\mathrm{T}$ helper cells and regulatory $\mathrm{T}$. CD8 is a transmembrane glycoprotein that serves as a co-receptor for the T cell receptor (TCR). Like the TCR, CD8 binds to a major histocompatibility complex (MHC) molecule, but it is specific for the class I MHC protein. CD20 is a non-glycosylated phosphoprotein expressed on the surface of all mature B-cells. CD20 is expressed at all stages of $\mathrm{B}$ cell development from prepre B cells through to memory cells (http://www.genecards.org).

It has recently become clear that analysis of the tumour stroma is paramount. This is because many anti-tumor effects operate mainly via the tumor stroma [13], and cancer infiltration by tumor reactive T-lymphocytes is required for efficient tumor eradication [14]. However, cancer cells can evade the immune system in many ways including suppression of cytotoxic T-cells by regulatory T-cells and by accumulation of myeloid suppressor cells [14-17].

Many studies have been designed to investigate the prognostic factors of STS using immunohistochemical methods [18]. Most of the published data has focused on the expression of markers for cell kinetics and regulatory proteins of the cell cycle. There are few studies of the prognostic impact of lymphocytes in STS [11].

\section{Methods}

The National Cancer Data Inspection Board and The Regional Committee for Research Ethics approved the study. The material was collected from our approved biobank for paraffin-embedded materials and slides. The Regional Committee confirmed that written consent from the patients for their information to be stored in the hospital database and used for research was not needed. This is because most of the material was more than 10 years old, and most of the patients were dead. The data was analyzed anonymously.

Primary tumor tissue from patients diagnosed with STS at the University Hospital of North Norway (UNN) from 1973 to 2006 and the Hospitals of
Arkhangelsk region, Russia, from 1996-2006 was used in this retrospective study. 496 potentially suitable patient records were identified from the hospital database but only 249 of these were eligible because in they had complete medical records and adequate paraffin-embedded tissue blocks. In 80 of these cases it was possible to obtain tissue from the peritumoral capsule for TMA.

This report includes follow-up data for 59 Norwegian and 21 Russian patients. The median follow-up was 38 (range 0-392) months. Complete demographic and clinical data were collected retrospectively. Formalin-fixed and paraffin-embedded tumor specimens were obtained from the archives of the Departments of Pathology at UNN and Arkhangelsk. The tumors were graded according to the French Fèdèration Nationales des Centres de Lutte Contre le Cancer (FNCLCC), [WHO Tumors of Soft Tissue and bone, 2002]. Wide resection margins were defined as wide local resection with free microscopic margins or amputation of the affected limb or organ. Non-wide resection margins were defined as either marginal or intra-lesional resection margins, or no surgery.

The histology of all soft tissue sarcoma cases was reviewed according to modern classification (WHO, 2002) by two pathologists (AV and SWS). For the Russian material there were made new slides of all the paraffin blocks. For the Norwegian material new slides were made when necessary. All the biopsies were immunostained with CK, CD117, Actin, SMA, VIM and CD34. Some slides were also stained with S100 if necessary to rule out differential diagnosis. Other molecular methods where not considered as necessary for differential diagnostics, but in some cases PCR or FISH were performed in the initial diagnostics. Ten of the initial diagnoses were revised due to changes of classification system and appearance of new entities as GIST. All carsinosarcomas, endometrial sarcomas, carcinomas and lymphomas were excluded.

There is some lymphocyte heterogeneity in tumor and capsule which gives variation on lymphocyte counts within tumours. TMAs are therefore not useful to estimate the prognosis of every single patient, but in large groups the mean expression will be representative for the group. In average the heterogeneity will not be a problem if the sample size is large enough. Usually 60 samples are considered to be enough to get a representative material. We had two cores from tumor and two cores from peritumoral capsule from 80 patients. If we had used three cores from the tumor and three cores from the peritumoral capsule we would secure the representativeness even more and reduce sampling errors, but we did not want to use too much tissue from the donor blocs. 


\section{Microarray construction}

Tissue microarrays (TMAs) were constructed for highthroughput molecular pathology research [19-21]. The slides were evaluated by two pathologists using a light microscope to identify the peritumoral capsule (AV and SWS). The most representative areas of the tumor and the peritumoral capsule were carefully selected and marked on the hematoxylin and eosin (HE) slides for the corresponding donor blocks and sampled for the tissue microarray collector blocks. Soft tissue sarcomas are by definition stromal tumores. But from a biological point of view any tissue must have both parenchyma and supporting stroma. For STS it can be both internal tissue and surrounding tissue. Therefore we have chosen to focus on the tumor capsule (pseudocapsule). We defined the peritumoral capsule as the 1-3 mm thick layer of connective tissue surrounding the parenchyma of the tumor. In high grade tumors there was no typical capsule, but in several of the cases it was a desmoplastic reaction in the surrounding tissues which was also obtained as capsule. The TMAs were assembled using a tissue-arraying instrument (Beecher Instruments).

Studies suggest that punching multiple $0.6 \mathrm{~mm}$ cores from different regions captures the heterogeneity of the capsule more accurately than single 2 to $4 \mathrm{~mm}$ cores [21]. Hence, we used two $0.6-\mathrm{mm}$ cores of the tumor and two cores from the peritumoral capsule that were taken from different areas and selected to be as representative as possible. To include all core samples, sixteen tissue array blocks were constructed. Multiple 4$\mu \mathrm{m}$ sections were cut with a Micron microtome (HM355S) and specific antibodies were stained for immunohistochemistry (IHC).

\section{Immunohistochemistry (IHC)}

The applied antibodies were subjected to in-house validation by the manufacturer for IHC analysis on paraffin-embedded material. Ventana Benchmark, XT automated slide stainer (Ventana Medical System, France) was used for IHC. Sections were de-paraffinized with xylene and rehydrated with ethanol. Antigen retrieval was performed by placing the specimens in $0.01 \mathrm{M}$ citrate buffer at $\mathrm{pH} 6.0$ and twice exposing to microwave heating for 10 minutes at $450 \mathrm{~W}$. The DAKO Envision + System-HRP (DAB) kit was used as endogen peroxidase blocking. As negative staining controls, the primary antibodies were replaced with the primary antibody diluents. Primary mouse monoclonal antibodies were incubated for 16 minutes (CD20, clone L26 Ventana); 20 minutes (CD4, clone 1 F6 Novocastra, dilution 1:5); and 32 minutes (CD8, clone $1 \mathrm{~A} 5 \mathrm{Ventana})$ at room temperature. The Ventana antibodies were pre-diluted by the manufacturer.
Biotinylated goat anti-mouse IgG and mouse anti-rabbit IgM were used as secondary antibodies. The DAB was used to make the antigens visible. This was followed by application of liquid diaminobenzidine and substratechromogen, yielding a brown reaction product at the site of the target antigen. Finally, slides were counterstained with hematoxylin to make the nuclei visible. TMA staining was performed in a single experiment for each antibody, including negative controls.

\section{Scoring of IHC}

The ARIOL imaging system (Genetix, San Jose, CA) was used to scan the slides for antibody staining of the TMAs. The specimens were scanned at a low resolution $(1.25 \times)$ and high resolution $(20 \times)$ using an Olympus BX 61 microscope with an automated platform (Prior). The slides were loaded in the automated slide loader (Applied Imaging SL 50). Representative and viable tissue sections from the peritumoral capsule were scored semi-quantitatively for lymphocyte membrane staining. For each core the tissues were scored manually on a computer screen as: 0 (no cells), 1 (1-5 cells), 2 (6-19 cells), or $3(20+$ cells) (Figure 1$)$. We have included all lymphocytes located within both inner and outer parts of the capsule. The score for each patient was based on the mean scorings of cores from the one or several biopsies. To achieve maximum reproducibility in all cases every staining was dichotomised (low and high expression). High expression was defined as mean score $\geq 1$ for all the immunomarkers (CD3, CD4, CD8 and CD20).

Of the 80 patients, we had three missing for immunostaining with CD20. Of the 77 patients with valid score, a total of 57 patients had the same score in both cores, and 20 had different scores. When the two cores from each tumor had different expression, we used the mean score. If the scores were 0 and 1 , the mean score was 0.5 . If the scores were 1 and 2 , the mean score was 1.5. In the first case, the mean score was $<1$ (low expression). In the second case, the mean score was $>1$ (high expression).

All samples were made anonymous and independently scored by two pathologists (AV and SWS). Where there was disagreement, the slides were re-examined and a consensus was reached by the observers. When assessing a variable for a given score, the scores of the other variables, and the outcome, were hidden from the observers.

\section{Statistical methods}

Statistical package SPSS (Chicago, IL), version 16 was used for all statistical analyses. The immunohistochemistry scores from each observer were compared for inter-observer reliability using a two-way random effect 

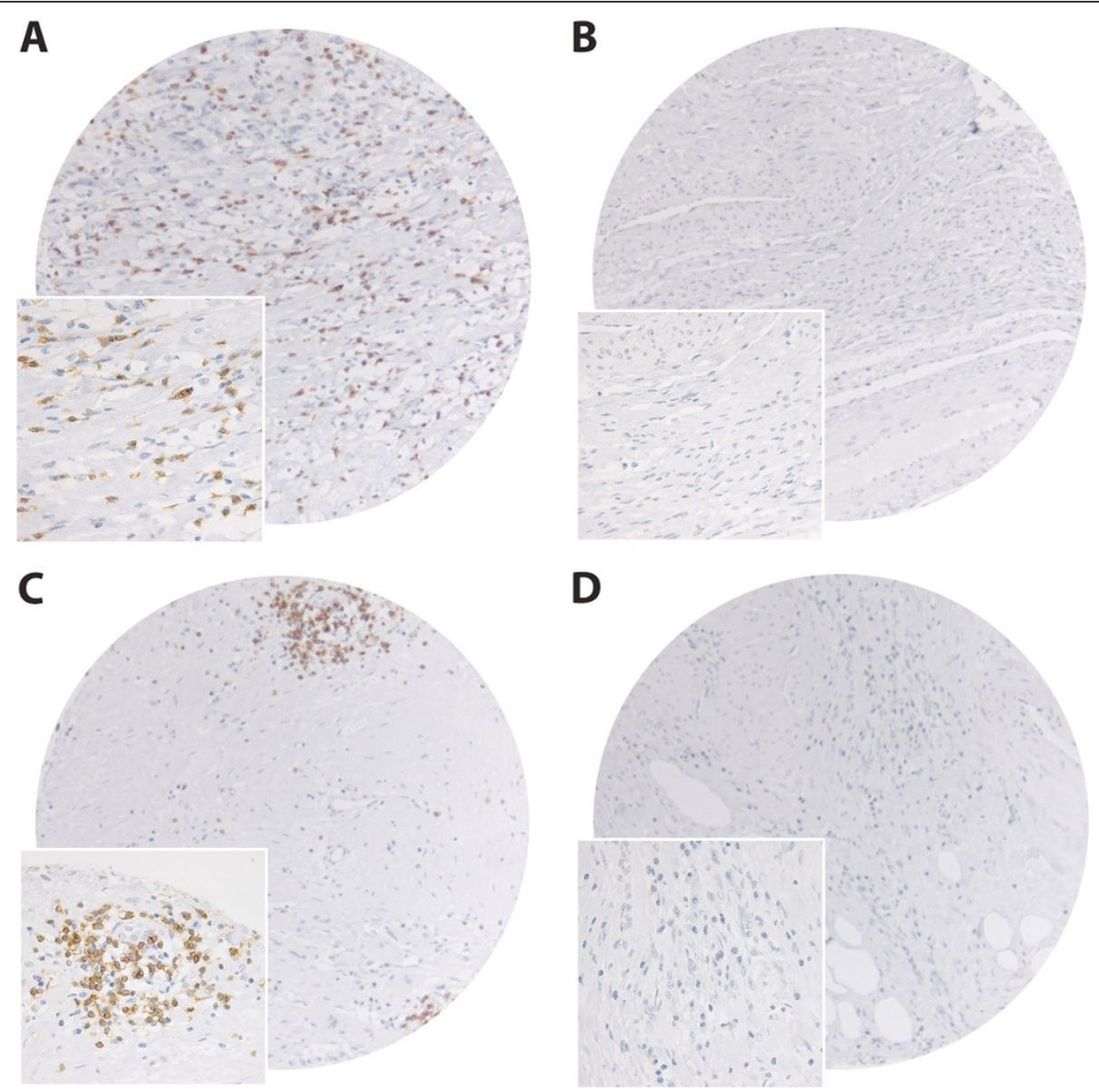

Figure 1 Pictures of tissue cores. IHC microscopic pictures of TMA of soft tissue sarcomas representing different scores for CD8+ and CD20+ lymphocytes in peritumoral capsule. (A) CD8 high score; (B) CD8 low score; (C) CD20 high score; (D) CD20 low score. Original magnification, $\times 100$ and $\times 400$.

model with absolute agreement definition. The intraclass correlation coefficient (reliability coefficient) was obtained from these results.

The Chi-square test and Fishers Exact test were used to examine the association between molecular marker expression and various clinicopathological parameters. Univariate analyses were carried out using the KaplanMeier method, and statistical significance between survival curves was assessed using the log rank test. Diseasespecific survival (DSS) was determined from the date of histological-confirmed STS diagnosis.

Multivariate analysis was carried out using the Cox proportional hazards model to assess the independent impact on survival of each pre-treatment variable in the presence of other variables. Only variables of significant value from the univariate analysis were entered into the Cox regression analysis. Probability for stepwise entry and removal was set at 0.05 and 0.10 , respectively. The significance level used was $p<0.05$.

\section{Results}

\section{Clinicopathological variables}

Demographic, clinical, and histopathological variables are shown in Table 1. Patient age range was 0-91 years (mean 56 years, median 59.5 years), and $44 \%$ of the patients were males. The non-GIST soft tissue sarcomas (STS) comprised: 20 undifferentiated pleomorphic sarcoma, 21 leiomyosarcoma, 7 angiosarcoma, 6 liposarcoma, 6 rhabdomyosarcoma, 6 synovial sarcoma, 5 malignant peripheral nerve sheath tumors (MPNST), 4 malignant fibroblastic/myofibroblastic tumors, and 5 other STS. There were 15 low grade (19\%) and 65 high grade (81\%, FNCLCC grade 2 and 3) STS.

\section{Interobserver variability}

There was good reproducibility between the two investigating pathologists. Their scoring agreement was tested for CD8 and CD20. The intra-class correlation coefficients (reliability coefficients, r) obtained from these 
Table 1 Clinicopathologic variables and surival.

\begin{tabular}{|c|c|c|c|c|c|}
\hline Characteristic & $\begin{array}{l}\text { Patients } \\
\text { (n) }\end{array}$ & $\begin{array}{l}\text { Patients } \\
(\%)\end{array}$ & Median survival (months) & $\begin{array}{c}\text { 5-Year survival } \\
(\%)\end{array}$ & $P$ \\
\hline \multicolumn{6}{|l|}{ Age } \\
\hline$\leq 20$ years & 7 & 9 & NR & 57 & 0.479 \\
\hline $21-60$ years & 36 & 45 & 63 & 53 & \\
\hline$>60$ years & 37 & 46 & 36 & 44 & \\
\hline \multicolumn{6}{|l|}{ Sex } \\
\hline Male & 35 & 44 & 63 & 50 & 0.847 \\
\hline Female & 45 & 56 & 57 & 49 & \\
\hline \multicolumn{6}{|l|}{ Nationality } \\
\hline Norwegian & 59 & 74 & 38 & 48 & 0.646 \\
\hline Russian & 21 & 26 & 127 & 52 & \\
\hline \multicolumn{6}{|l|}{ Histology } \\
\hline Undifferentiated pleomorphic sarcoma & 20 & 25 & 127 & 57 & 0.025 \\
\hline Leiomyosarcoma & 21 & 26 & 67 & 52 & \\
\hline Angiosarcoma & 7 & 9 & 15 & 29 & \\
\hline Liposarcoma & 6 & 8 & 36 & 50 & \\
\hline Rhabdomyosarcoma & 6 & 8 & 32 & 50 & \\
\hline Synovial sarcoma & 6 & 8 & 31 & 50 & \\
\hline MPNST & 5 & 6 & NR & 80 & \\
\hline MF/MFT & 4 & 5 & 15 & 50 & \\
\hline Other STS & 5 & 6 & 11 & 0 & \\
\hline \multicolumn{6}{|l|}{ Tumor localization } \\
\hline Extremities & 31 & 39 & 123 & 61 & 0.447 \\
\hline Trunk & 15 & 19 & 32 & 47 & \\
\hline Retroperitoneum & 11 & 14 & 57 & 42 & \\
\hline Head/Neck & 5 & 6 & 15 & 20 & \\
\hline Pelvis & 18 & 23 & 22 & 41 & \\
\hline \multicolumn{6}{|l|}{ Tumor size } \\
\hline$\leq 5 \mathrm{~cm}$ & 26 & 33 & 67 & 54 & 0.800 \\
\hline $5-10 \mathrm{~cm}$ & 33 & 41 & 31 & 45 & \\
\hline$>10 \mathrm{~cm}$ & 20 & 25 & 80 & 53 & \\
\hline Missing & 1 & 1 & & & \\
\hline \multicolumn{6}{|l|}{ Malignancy grade FNCLCC } \\
\hline 1 & 15 & 19 & NR & 70 & 0.007 \\
\hline 2 & 31 & 39 & 80 & 61 & \\
\hline 3 & 34 & 43 & 15 & 29 & \\
\hline \multicolumn{6}{|l|}{ Tumor depth } \\
\hline Superficial & 4 & 5 & NR & 100 & 0.046 \\
\hline Deep & 76 & 95 & 32 & 46 & \\
\hline \multicolumn{6}{|l|}{ Operated } \\
\hline Yes & 73 & 91 & 75 & 54 & $<0.001$ \\
\hline No & 7 & 9 & 5 & 0 & \\
\hline \multicolumn{6}{|l|}{ Surgical margins } \\
\hline Wide & 39 & 49 & NR & 67 & $<0.001$ \\
\hline Non-wide & 41 & 51 & 18 & 32 & \\
\hline
\end{tabular}


Table 1 Clinicopathologic variables and surival. (Continued)

\begin{tabular}{|c|c|c|c|c|c|}
\hline \multicolumn{6}{|c|}{ Metastasis at diagnosis } \\
\hline No & 65 & 81 & 80 & 57 & \multirow[t]{2}{*}{$<0.001$} \\
\hline Yes & 15 & 19 & 11 & 14 & \\
\hline \multicolumn{6}{|c|}{ Chemotherapy } \\
\hline No & 59 & 74 & 36 & 46 & \multirow[t]{2}{*}{0.147} \\
\hline Yes & 21 & 26 & NR & 57 & \\
\hline \multicolumn{6}{|c|}{ Radiotherapy } \\
\hline No & 60 & 75 & 38 & 47 & \multirow[t]{2}{*}{0.775} \\
\hline Yes & 20 & 25 & 63 & 55 & \\
\hline
\end{tabular}

Prognostic clinicopathologic variables as predictors for disease-specific survival in soft tissue sarcomas with peritumoral capsule (univariate analysis, log rank test), $\mathrm{N}=80$ Abbreviations: MF/MFT, malignant fibroblastic/myofibroblastic tumors; MPNST, malignant peripheral nerve sheath tumor; STS, soft tissue sarcomas; NR, not reached Ninety-one percent $(n=73)$ underwent surgery. The 5-year survival with non-wide resection margins was $32 \%$ and with wide resection margins it was $67 \%$.

results were 0.90 for CD8 $(P<0.001)$ and 0.90 for CD20 $(P<0.001)$.

\section{Univariate analysis}

Histological entity, malignancy grade, tumor depth, surgery, surgical margins and metastasis at time of diagnosis were all significant indicators for disease-free survival (DSS) in univariate analyses (Table 1).

Increasing numbers of CD20+ $(P=0.032)$ lymphocytes in the peritumoral capsule were significantly associated with a reduced DSS. No such relationship was apparent for $\mathrm{CD} 3+, \mathrm{CD} 4+$ and CD8+ lymphocytes (Table 2 Figure 2). In subgroup analysis increasing numbers of CD20+ lymphocytes were significantly associated with a reduced DSS in patients over 60 years $(P<$
0.001), patients with high grade tumors $(P=0.012)$, and patients without wide surgical resection margins $(P=$ 0.003) (data not shown). There were no such associations of lymphocyte infiltration in the tumor (Table 2).

\section{Multivariate analyses}

Significant demographic, clinicopathological, and lymphocyte infiltrate variables from the univariate analyses were entered into the multivariate Cox regression analysis. We did not undertake a multivariate analysis of lymphocyte counts with CD20 in the tumor, because in this dataset there was no statistical significance on prognosis of CD20 counts in the tumor. A high number of CD20 lymphocytes in the peritumoral capsule had an independent negative survival impact (HR 2.7, CI95\% 1.10-6.60,

Table 2 Expression of markers and survival.

\begin{tabular}{|c|c|c|c|c|c|c|c|c|c|c|}
\hline & & & Tumor & & & & & Peritumoral caps & & \\
\hline $\begin{array}{c}\text { Marker } \\
\text { expression }\end{array}$ & $\begin{array}{l}\text { Patients } \\
\text { (n) }\end{array}$ & $\begin{array}{l}\text { Patients } \\
\text { (\%) }\end{array}$ & $\begin{array}{l}\text { Median survival } \\
\text { (months) }\end{array}$ & $\begin{array}{c}5 \text {-Year } \\
\text { survival (\%) }\end{array}$ & $\mathbf{P}$ & $\begin{array}{l}\text { Patients } \\
\text { (n) }\end{array}$ & $\begin{array}{l}\text { Patients } \\
\text { (\%) }\end{array}$ & $\begin{array}{l}\text { Median survival } \\
\text { (months) }\end{array}$ & $\begin{array}{c}5 \text {-Year } \\
\text { survival (\%) }\end{array}$ & $P$ \\
\hline \multicolumn{11}{|l|}{ CD 3} \\
\hline Low & 56 & 70 & 80 & 54 & 0.207 & 29 & 36 & 32 & 47 & 0.756 \\
\hline High & 19 & 24 & 27 & 36 & & 40 & 50 & 67 & 56 & \\
\hline Missing & 5 & 6 & & & & 11 & 14 & & & \\
\hline \multicolumn{11}{|l|}{ CD 4} \\
\hline Low & 64 & 80 & 57 & 49 & 0.887 & 45 & 56 & 52 & 51 & 0.654 \\
\hline High & 14 & 18 & 27 & 50 & & 35 & 44 & 57 & 53 & \\
\hline Missing & 2 & 3 & & & & 10 & 12 & & & \\
\hline \multicolumn{11}{|l|}{ CD 8} \\
\hline Low & 64 & 80 & 80 & 54 & 0.198 & 47 & 59 & 67 & 52 & 0.838 \\
\hline High & 14 & 18 & 15 & 36 & & 26 & 32 & 38 & 50 & \\
\hline Missing & 2 & 3 & & & & 7 & 9 & & & \\
\hline \multicolumn{11}{|l|}{ CD 20} \\
\hline Low & 56 & 70 & 63 & 50 & 0.880 & 65 & 81 & 75 & 55 & 0.032 \\
\hline High & 22 & 28 & 32 & 50 & & 12 & 15 & 13 & 33 & \\
\hline Missing & 2 & 3 & & & & 3 & 4 & & & \\
\hline
\end{tabular}

Peritumoral capsule lymphocyte subsets and their prediction for disease-specific survival in patients with soft tissue sarcomas (univariate analysis; log-rank test), $\mathrm{N}=80$ 


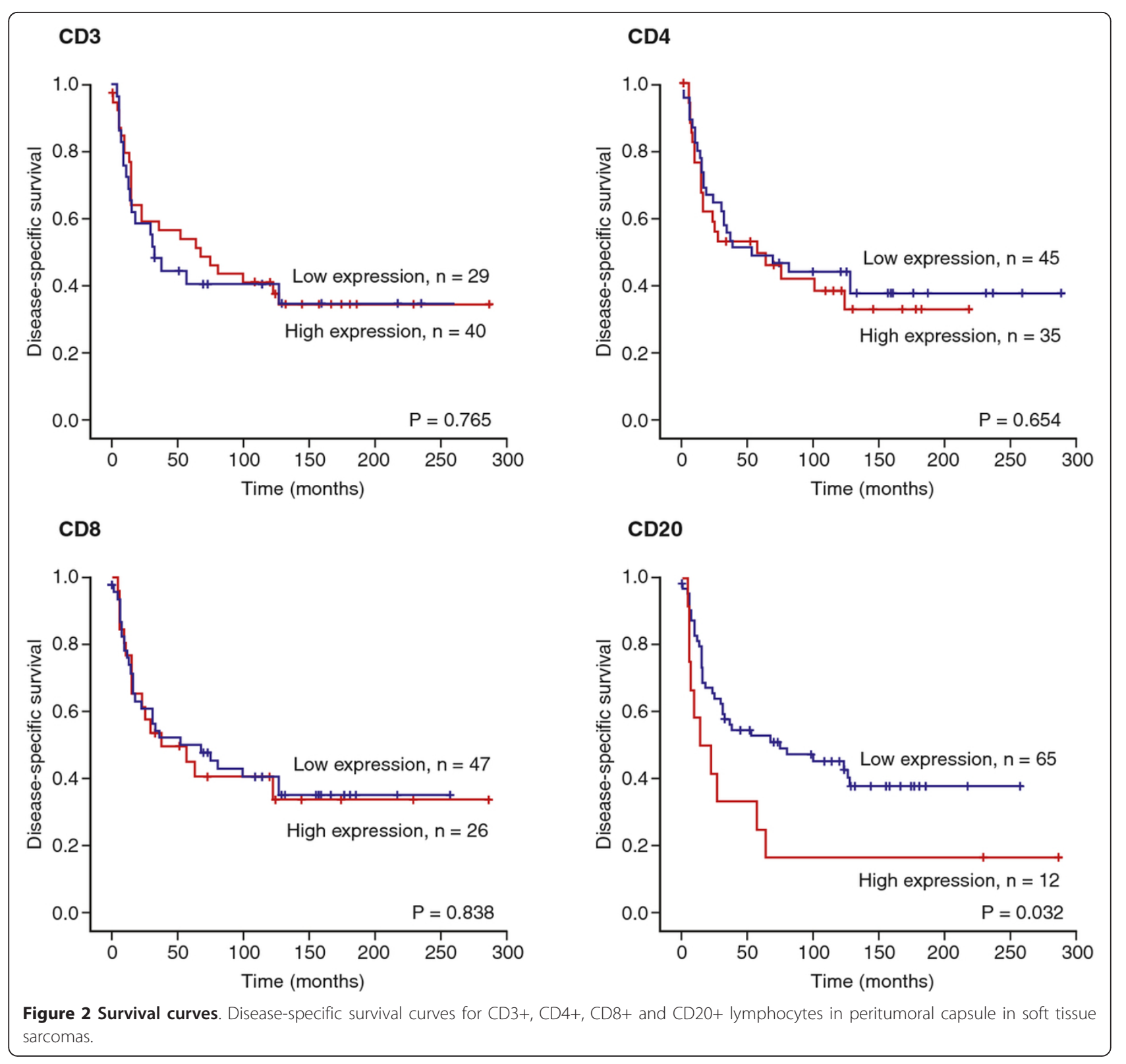

$P=0.030)$. Other independent prognostic variables were malignancy grade $(P=0.001)$, surgical operation $(P<$ $0.010)$, and surgical margins $(P<0.001)$, (Table 3$)$.

\section{Discussion}

In this study, we evaluate the prognostic impact of $\mathrm{CD} 3$ ,$+ \mathrm{CD} 4+, \mathrm{CD} 8+$ and CD20+ lymphocytes in the peritumoral capsule and associations with clinico-pathological variables in 80 non-GIST STS. To our knowledge, this is the first study of the association between lymphocyte infiltration in the peritumoral capsule and DSS in STS patients. Interestingly, high numbers of CD20+ cells in the capsule was an independent negative prognostic factor for DSS.
Tumor infiltrating CD20+ B-cells are correlated with an improved DSS in lung cancer, prostate cancer, ovarian cancer and STS [11,22-25]. Tumor infiltrating lymphocytes are considered to be an indication of the host immune reaction to tumor antigens [26]. Pelletier studied several prognostic factors in 113 NSCLC tumors, including peritumoral B (CD20+) and T (CD43+) lymphocytes, and found $\mathrm{B}$ cells to be associated with an improved DSS [25]. Peritumoral lymphocytes in epithelial tumors may have different significance from lymphocytes in the capsule in stromal tumors. In our study, high numbers of CD20 cells in the capsule were an independent negative prognostic factor for DSS in STS. Tumor-associated inflammation is a chronic process 
Table 3 Results of Cox regression analysis in peritumoral capsule summarizing prognostic factors, $\mathbf{N}=\mathbf{8 0}$

\begin{tabular}{cccc}
\hline Factor & Hazard Ratio & $95 \% \mathrm{Cl}$ & $\mathbf{P}$ \\
\hline Tumor size & & & $0.780^{*}$ \\
$\leq 5 \mathrm{~cm}$ & 1.000 & & \\
$5-10 \mathrm{~cm}$ & 1.328 & $0.601-2.933$ & 0.484 \\
$>10 \mathrm{~cm}$ & 1.268 & $0.505-3.186$ & 0.613 \\
Malignancy grade FNCLCC & & & 0.001 \\
1 & 1.000 & & \\
2 & 3.481 & $0.899-$ & 0.071 \\
3 & & 13.470 & \\
& 8.448 & $2.285-$ & 0.001 \\
Operated & & 31.230 & \\
Yes & & & \\
No & 1.000 & & \\
Surgical margins & 5.594 & $1.504-$ & 0.010 \\
Wide & & 20.812 & \\
Non-wide & 1.000 & & \\
No & 3.633 & $1.768-7.463$ & $<0.001$ \\
Yes & & & \\
CD20 + cells & 1.000 & & \\
Low & 2.088 & $0.977-4.463$ & 0.057 \\
High & & & \\
Metastasis at time of diagnosis & 1.000 & & \\
Now & 2.696 & $1.102-6.598$ & 0.030 \\
\hline
\end{tabular}

* Overall significance as a prognostic factor

which is often unfavorable for the host [27]. The precipitation of immunoglobulin in the tissue may have a stimulatory effect on the innate immune cells, which may enhance tumor growth by secreting mediators which stimulate angiogenesis [12]. Many immune cells found in the tumor microenvironment may be associated with the tissue disruption caused by inflammatory agents or they may be a response to tumor growth [27]. In fact, de Visser et al. showed in an animal model that B lymphocytes are required for establishing chronic inflammatory states that promote de novo carcinogenesis [28]. However, it is possible that B regs might accumulate at the tumor site.

There has been significant progress in cancer immunotherapy during the last decade [27]. Progress in understanding the molecular mechanisms that govern immune activation, as well as the mechanisms used by tumor cells to evade surveillance by the immune system, are advancing the development of immune-mediated therapies that could be used against a range of human cancers [29].

Evidence on the role of the immune system in limiting tumor growth and progression is linked to observations indicating a positive correlation between the presence of tumor infiltrating CD8+ T-cells and good prognosis in various types of cancer [30]. CD8+ cells in malignant tumors have been associated with an improved DSS in: non-small cell lung carcinoma; carcinomas of the endometrium, bile duct, colon, oesophagus, and urothelium; uveal melanoma; and follicular lymphoma [22,31-40]. Tumor infiltrating CD8+ lymphocytes were not associated with improved survival in STS [11]. However, in mice with solid sarcoma EGF-SEA, CD4+, CD8+ and SEA-reactive $\mathrm{T}$ lymphocytes strongly suppressed tumor growth [41].

The role of CD8 + lymphocytes in the peritumoral capsule of STS is unknown. The location of infiltrating lymphocytes may be important. There are major differences between 1) lymphocytes within cancer cell nests in carcinomas (epithelial lymphocytes); 2) lymphocytes present along the invasive margins (peritumoral lymphocytes); and, 3) lymphocytes in the capsule of stromal tumors such as STS. Galon et al. investigated the relationship between the type, density, and location of immune cells within tumors and the clinical outcome of patients with colorectal carcinomas. They found that patients with low densities of CD3+ cells, CD8+ and $\mathrm{CD} 45 \mathrm{RO}+$ memory $\mathrm{T}$ cells in both the centre of the tumor and the invasive margins had a very poor prognosis [32]. High expression of tumor infiltrating CD3+ $\mathrm{T}$-cells is associated with good prognosis in various types of cancers [30]. High number of CD8+ cytotoxic T-lymphocytes infiltrating primary and metastatic ovarian cancer sites are associated with improved prognosis [42]. In our material there was no significant correlation between DSS and CD3+ or CD8+ infiltrating cells in the capsule.

The role of $\mathrm{CD} 4+\mathrm{T}$ and $\mathrm{B}$ lymphocytes is controversial in many cancers including STS [30]. In the absence of CD8+ cytotoxic T cells CD4+ cells are critical, and sufficient for NKT cell-dependent rejection of experimental tumours [43]. There was a positive correlation between a high density of CD4+ and CD8+ lymphocytes in stroma and improved disease-specific survival in nonsmall cell lung cancer [22]. In our material we did not find any significant correlation between DSS and CD4+ infiltrating cells in the capsule.

In a previous paper we reported that high density of CD20+ lymphocytes in tumor of STS is an independent positive prognostic indicator in 108 patients with wide resection margins [11], but not when the 141 patients with non-wide resection margins were included in the analysis. In this paper only 39 patients with material from the peritumoral capsule had wide resection margins and there was no effect on prognosis of CD20 counts in tumor. However, a high density of CD20+ lymphocytes in the peritumoral capsule is a negative prognostic indicator for patients with STS, independent of resection margins. 


\section{Conclusions}

High density of CD20+ peritumoral lymphocytes is an independent negative prognostic indicator for patients with STS. These data need to be verified in larger-scale studies. Furthermore, experimentally designed research is required in order to define whether CD20 cells in the peritumoral capsule of STS promote tumor invasion and/or metastasis.

\section{Acknowledgements}

Thanks to Frode Skjold for coupling of databases and Magnus L. Persson for making the TMA blocks.

\section{Author details}

'Dept of Clinical Pathology, University Hospital of North Norway, 9038 Tromso, Norway. ${ }^{2}$ Institute of Medical Biology, University of Tromso, Tromso, Norway. ${ }^{3}$ Dept of Oncology, University Hospital of North Norway, Tromso, Norway. ${ }^{4}$ Institute of Clinical Medicine, University of Tromso, Tromso, Norway. ${ }^{5}$ Dept of Pathology, Nordland Central Hospital, Bodo, Norway.

\section{Authors' contributions}

SWS, TK, AV, TD, RMB and LTB participated in the design of the study. TK and $A V$ collected clinical information. SWS and AV reviewed all the histological diagnosis, histological grading, selected and marked the slides for TMA construction. SWS, TK and AV performed the experiments. SWS, TK, $A V, T D, R M B$ and LTB performed the statistical analysis. SWS, TK, AV, TD, ES, KAS and LTB contributed reagents/materials/analysis tools. SWS, TD, ES, KAS, RMB and LTB drafted the manuscript. All authors read and approved the final manuscript.

\section{Competing interests}

The authors declare that they have no competing interests.

Received: 7 December 2011 Accepted: 29 February 2012

Published: 29 February 2012

\section{References}

1. Gustafson P: Soft tissue sarcoma. Epidemiology and prognosis in $\mathbf{5 0 8}$ patients. Acta Orthop Scand Supp/ 1994, 259:1-31.

2. Engellau J, Anderson H, Rydholm A, Bauer HC, Hall KS, Gustafson P, Akerman M, Meis-Kindblom J, Alvegard TA, Nilbert M: Time dependence of prognostic factors for patients with soft tissue sarcoma: a Scandinavian Sarcoma Group Study of 338 malignant fibrous histiocytomas. Cancer 2004, 100:2233-2239.

3. Dickinson IC, Whitwell DJ, Battistuta D, Thompson B, Strobel N, Duggal A, Steadman P: Surgical margin and its influence on survival in soft tissue sarcoma. ANZ J Surg 2006, 76:104-109.

4. Kiatisevi $P$, Asavamongkolkul A, Phimolsarnti R, Waikakul S, Benjarassamerote $\mathrm{S}$ : The outcomes and prognostic factors of patients with soft-tissue sarcoma. J Med Assoc Thai 2006, 89:334-342.

5. Koea JB, Leung D, Lewis JJ, Brennan MF: Histopathologic type: an independent prognostic factor in primary soft tissue sarcoma of the extremity? Ann Surg Oncol 2003, 10:432-440.

6. Mendenhall WM, Zlotecki RA, Hochwald SN, Hemming AW, Grobmyer SR, Cance WG: Retroperitoneal soft tissue sarcoma. Cancer 2005, 104:669-675.

7. Raney RB Jr, Crist WM, Maurer HM, Foulkes MA: Prognosis of children with soft tissue sarcoma who relapse after achieving a complete response. A report from the Intergroup Rhabdomyosarcoma Study I. Cancer 1983, 52:44-50.

8. Yang RS, Lane JM, Eilber FR, Dorey FJ, al Shaikh R, Schumacher LY, Rosen G Forscher CA, Eckardt JJ: High grade soft tissue sarcoma of the flexor fossae. Size rather than compartmental status determine prognosis. Cancer 1995, 76:1398-1405.

9. Zagars GK, Ballo MT, Pisters PW, Pollock RE, Patel SR, Benjamin RS: Prognostic factors for disease-specific survival after first relapse of softtissue sarcoma: analysis of 402 patients with disease relapse after initial conservative surgery and radiotherapy. Int J Radiat Oncol Biol Phys 2003, 57:739-747.

10. Wakabayashi O, Yamazaki K, Oizumi S, Hommura F, Kinoshita I, Ogura S, Dosaka-Akita H, Nishimura M: CD4+ T cells in cancer stroma, not CD8+ T cells in cancer cell nests, are associated with favorable prognosis in human non-small cell lung cancers. Cancer Sci 2003, 94:1003-1009.

11. Sorbye SW, Kilvaer T, Valkov A, Donnem T, Smeland E, Al Shibli K, Bremnes RM, Busund LT: Prognostic impact of lymphocytes in soft tissue sarcomas. PLoS One 2011, 6:e14611.

12. de Visser KE, Eichten A, Coussens LM: Paradoxical roles of the immune system during cancer development. Nat Rev Cancer 2006, 6:24-37.

13. Blankenstein $\mathrm{T}$ : The role of tumor stroma in the interaction between tumor and immune system. Curr Opin Immunol 2005, 17:180-186.

14. Mukai S, Kjaergaard J, Shu S, Plautz GE: Infiltration of tumors by systemically transferred tumor-reactive T lymphocytes is required for antitumor efficacy. Cancer Res 1999, 59:5245-5249.

15. Prendergast GC: Immune escape as a fundamental trait of cancer: focus on IDO. Oncogene 2008, 27:3889-3900.

16. Costello RT, Gastaut JA, Olive D: Tumor escape from immune surveillance. Arch Immunol Ther Exp (Warsz) 1999, 47:83-88.

17. Enarsson K, Lundin BS, Johnsson E, Brezicka T, Quiding-Jarbrink M: CD4+ CD25high regulatory $T$ cells reduce $T$ cell transendothelial migration in cancer patients. Eur J Immunol 2007, 37:282-291.

18. Ottaiano A, De Chiara A, Fazioli F, Talamanca AA, Mori S, Botti G, Milano A, Apice G: Biological prognostic factors in adult soft tissue sarcomas. Anticancer Res 2005, 25:4519-4526.

19. Bremnes RM, Veve R, Gabrielson E, Hirsch FR, Baron A, Bemis L, Gemmill RM, Drabkin HA, Franklin WA: High-throughput tissue microarray analysis used to evaluate biology and prognostic significance of the Ecadherin pathway in non-small-cell lung cancer. J Clin Oncol 2002, 20:2417-2428.

20. Donnem T, Al Saad S, Al Shibli K, Delghandi MP, Persson M, Nilsen MN, Busund LT, Bremnes RM: Inverse prognostic impact of angiogenic marker expression in tumor cells versus stromal cells in non small cell lung cancer. Clin Cancer Res 2007, 13:6649-6657.

21. Nocito A, Kononen J, Kallioniemi OP, Sauter G: Tissue microarrays (TMAs) for high-throughput molecular pathology research. Int J Cancer 2001, 94:1-5.

22. Al Shibli Kl, Donnem T, Al Saad S, Persson M, Bremnes RM, Busund LT: Prognostic effect of epithelial and stromal lymphocyte infiltration in non-small cell lung cancer. Clin Cancer Res 2008, 14:5220-5227.

23. Karja V, Aaltomaa S, Lipponen P, Isotalo T, Talja M, Mokka R: Tumourinfiltrating lymphocytes: A prognostic factor of PSA-free survival in patients with local prostate carcinoma treated by radical prostatectomy. Anticancer Res 2005, 25:4435-4438.

24. Milne K, Kobel M, Kalloger SE, Barnes RO, Gao D, Gilks CB, Watson PH, Nelson $\mathrm{BH}$ : Systematic analysis of immune infiltrates in high-grade serous ovarian cancer reveals CD20, FoxP3 and TIA-1 as positive prognostic factors. PLoS One 2009, 4:e6412.

25. Pelletier MP, Edwardes MD, Michel RP, Halwani F, Morin JE: Prognostic markers in resectable non-small cell lung cancer: a multivariate analysis. Can J Surg 2001, 44:180-188.

26. Dunn GP, Bruce AT, Ikeda H, Old LJ, Schreiber RD: Cancer immunoediting: from immunosurveillance to tumor escape. Nat Immunol 2002, 3:991-998.

27. Bremnes RM, Al Shibli K, Donnem T, Sirera R, Al Saad S, Andersen S, Stenvold H, Camps C, Busund LT: The Role of Tumor-Infiltrating Immune Cells and Chronic Inflammation at the Tumor Site on Cancer Development, Progression, and Prognosis: Emphasis on Non-small Cell Lung Cancer. J Thorac Oncol 2011, 6:824-833.

28. de Visser KE, Korets LV, Coussens LM: De novo carcinogenesis promoted by chronic inflammation is B lymphocyte dependent. Cancer Cell 2005, 7:411-423.

29. Palena C, Schlom J: Vaccines against human carcinomas: strategies to improve antitumor immune responses. J Biomed Biotechnol 2010, 2010:380697.

30. Gooden M, Lampen M, Jordanova ES, Leffers N, Trimbos JB, van der Burg SH, Nijman $\mathrm{H}$, van Hall $\mathrm{T}$ : The prognostic influence of tumourinfiltrating lymphocytes in cancer: a systematic review with metaanalysis. Proc Natl Acad Sci USA 2011, 108(26):10656-10661.

31. Eerola AK, Soini Y, Paakko P: A high number of tumor-infiltrating lymphocytes are associated with a small tumor size, low tumor stage, 
and a favorable prognosis in operated small cell lung carcinoma. Clin Cancer Res 2000, 6:1875-1881.

32. Galon J, Costes A, Sanchez-Cabo F, Kirilovsky A, Mlecnik B, Lagorce-Pages C, Tosolini M, Camus M, Berger A, Wind P, et al: Type, density, and location of immune cells within human colorectal tumors predict clinical outcome. Science 2006, 313:1960-1964.

33. Kondratiev S, Sabo E, Yakirevich E, Lavie O, Resnick MB: Intratumoral CD8+ $T$ lymphocytes as a prognostic factor of survival in endometrial carcinoma. Clin Cancer Res 2004, 10:4450-4456.

34. Naito Y, Saito K, Shiiba K, Ohuchi A, Saigenji K, Nagura H, Ohtani H: CD8+ T cells infiltrated within cancer cell nests as a prognostic factor in human colorectal cancer. Cancer Res 1998, 58:3491-3494.

35. Oshikiri T, Miyamoto M, Shichinohe T, Suzuoki M, Hiraoka K, Nakakubo Y Shinohara T, Itoh T, Kondo S, Katoh H: Prognostic value of intratumoral CD8+ T lymphocyte in extrahepatic bile duct carcinoma as essential immune response. J Surg Oncol 2003, 84:224-228.

36. Pages F, Berger A, Camus M, Sanchez-Cabo F, Costes A, Molidor R, Mlecnik B, Kirilovsky A, Nilsson M, Damotte D, et al: Effector memory T cells, early metastasis, and survival in colorectal cancer. N Engl J Med 2005, 353:2654-2666.

37. Schumacher K, Haensch W, Roefzaad C, Schlag PM: Prognostic significance of activated CD8(+) T cell infiltrations within esophageal carcinomas. Cancer Res 2001, 61:3932-3936.

38. Sharma P, Shen $Y$, Wen S, Yamada S, Jungbluth AA, Gnjatic S, Bajorin DF, Reuter VE, Herr $\mathrm{H}$, Old LJ, et al: CD8 tumor-infiltrating lymphocytes are predictive of survival in muscle-invasive urothelial carcinoma. Proc Natl Acad Sci USA 2007, 104:3967-3972.

39. Staibano S, Mascolo M, Tranfa F, Salvatore G, Mignogna C, Bufo P, Nugnes L, Bonavolonta G, De Rosa G: Tumor infiltrating lymphocytes in uveal melanoma: a link with clinical behavior? Int J Immunopathol Pharmacol 2006, 19:171-179.

40. Wahlin BE, Sander B, Christensson B, Kimby E: CD8+ T-cell content in diagnostic lymph nodes measured by flow cytometry is a predictor of survival in follicular lymphoma. Clin Cancer Res 2007, 13:388-397.

41. Sun J, Zhao L, Teng L, Lin F, Zhang H, Li Z, Gao Q: Solid tumor-targeted infiltrating cytotoxic $T$ lymphocytes retained by a superantigen fusion protein. PLoS One 2011, 6:e16642.

42. Leffers N, Gooden MJ, de Jong RA, Hoogeboom BN, ten Hoor KA, Hollema H, Boezen HM, van der Zee AG, Daemen T, Nijman HW: Prognostic significance of tumor-infiltrating T-lymphocytes in primary and metastatic lesions of advanced stage ovarian cancer. Cancer Immunol Immunother 2009, 58(3):449-459.

43. Hong C, Lee H, Oh M, Kang CY, Hong S, Park SH: CD4+ T cells in the absence of the CD8+ cytotoxic T cells are critical and sufficient for NKT cell-dependent tumor rejection. J Immunol 2006, 177:6747-6757.

\section{Pre-publication history}

The pre-publication history for this paper can be accessed here: http://www.biomedcentral.com/1472-6890/12/5/prepub

doi:10.1186/1472-6890-12-5

Cite this article as: Sorbye et al:: Prognostic impact of peritumoral lymphocyte infiltration in soft tissue sarcomas. BMC Clinical Pathology 2012 12:5.

\section{Submit your next manuscript to BioMed Central and take full advantage of:}

- Convenient online submission

- Thorough peer review

- No space constraints or color figure charges

- Immediate publication on acceptance

- Inclusion in PubMed, CAS, Scopus and Google Scholar

- Research which is freely available for redistribution

Submit your manuscript at www.biomedcentral.com/submit
Ciomed Central 